Case Reports in
Gastroenterology
Case Rep Gastroenterol 2021;15:424-430

DOI: 10.1159/000514394

Published online: April 19, 2021
(C) 2021 The Author(s)

Published by S. Karger AG, Base www.karger.com/crg

This article is licensed under the Creative Commons Attribution-NonCommercial 4.0 International License (CC BY-NC) (http://www.karger.com/Services/OpenAccessLicense). Usage and distribution for commercial purposes requires written permission.

\title{
Castleman's Disease Arising from the Hepatoduodenal Ligament Mimicking a Duodenal Gastrointestinal Stromal Tumor
}

\author{
Koichi Oishia, ${ }^{a} \quad$ Kazuhiro Toyota ${ }^{a}$ Manabu Shimomura ${ }^{a}$ \\ Tadateru Takahashi ${ }^{a, c}$ \\ ${ }^{a}$ Department of Surgery, National Hospital Organization Higashihiroshima Medical \\ Center, Higashihiroshima, Japan; 'bepartment of Surgery, Chugoku Rosai Hospital, \\ Kure, Japan; 'Department of Gastroenterological and Transplant Surgery, Applied Life \\ Sciences, Institute of Biomedical and Health Sciences, Hiroshima University, \\ Hiroshima, Japan
}

\section{Keywords}

Castleman's disease · Duodenal gastrointestinal stromal tumor · Hepatoduodenal ligament

\begin{abstract}
Castleman's disease (CD) arising from the hepatoduodenal ligament is extremely rare. A 32year-old man was referred to a clinic with nausea. He was found to have an abdominal mass by ultrasonography and consulted our hospital for further examination. Computed tomography revealed an equally enhancing mass, $5.2 \mathrm{~cm}$ in diameter, adjacent to the duodenum. On magnetic resonance imaging, the mass revealed a slightly iso-intensity signal equal to smooth muscle on T1-weighted imaging, a slightly high-intensity signal on T2-weighted imaging, and a high-intensity signal on diffusion-weighted imaging. Endoscopic ultrasonography showed a well-demarcated hypoechoic mass adjacent to the duodenum. The Doppler echo pattern indicated abundant blood flow. The preoperative diagnosis was a duodenal gastrointestinal stromal tumor. The patient underwent laparotomy and tumor excision. The finding of the intraoperative frozen section was CD. Histologically, the lymph follicles were markedly increased in number throughout the cortex and medulla with vascular proliferation and hyalinization in the intra- or extra-follicles. The germinal centers were atrophic and surrounded by
\end{abstract}

Karger $\quad \begin{aligned} & \text { Koichi Oishi } \\ & \text { Department of Surgery } \\ & \text { Chugoku Rosai Hospital } \\ & 1-5-1 \text { Hiro Tagaya, Kure 737-0193 (Japan) } \\ & \text { koishi@enjoy.ne.jp }\end{aligned}$




\section{Case Reports in Gastroenterology}

Case Rep Gastroenterol 2021;15:424-430

DOI: $10.1159 / 000514394$

(c) 2021 www.karger.com/crg

Oishi et al.: Castleman's Disease Arising from the Hepatoduodenal Ligament Mimicking a Duodenal Gastrointestinal Stromal Tumor

concentrically arranged layers of small lymphocytes. The histological findings were the hyaline vascular variant of $C D$. If a hypervascular solid mass is detected in the abdomen, $C D$ should be considered in the differential diagnosis.

\section{Introduction}

Castleman's disease (CD), initially described by Castleman in 1954, is a relatively rare lymphoproliferative disease [1]. The most common site of CD is the mediastinum, and CD in the abdomen is rare, with $\mathrm{CD}$ arising from the hepatoduodenal ligament being extremely rare. Clinically, $\mathrm{CD}$ is classified into unicentric CD (uCD) and multicentric CD (mCD). It is difficult to discriminate $\mathrm{CD}$ (especially $\mathrm{uCD}$ ) from malignant disease preoperatively. Gastrointestinal stromal tumor (GIST) is the most common subepithelial tumor of the gastrointestinal tract. Radiologically, when a subepithelial tumor larger than $3 \mathrm{~cm}$ shows hypervascularity on contrast-enhanced computed tomography (CT), GIST should be considered first in the differential diagnosis. As the CT features of CD are similar to those of GIST, differentiating between CD and GIST is difficult. We herein report a case of CD arising from the hepatoduodenal ligament mimicking a duodenal GIST preoperatively.

\section{Case Presentation}

A 32-year-old man was referred to a clinic with a chief complaint of nausea. He had no remarkable medical or family history. He was found to have an abdominal mass by ultrasonography and consulted our hospital for a further examination. CT revealed an equally enhancing mass, $5.2 \mathrm{~cm}$ in diameter, adjacent to the duodenum (Fig. 1a). On magnetic resonance imaging (MRI), the mass revealed a slightly iso-intensity signal equal to smooth muscle on T1weighted imaging (Fig. 1d), a slightly high-intensity signal on T2-weighted imaging (Fig. 1e), and a high-intensity signal on diffusion-weighted imaging (Fig. 1f). Endoscopic ultrasonography (EUS) showed a well-demarcated hypoechoic mass adjacent to the duodenum. The Doppler echo pattern indicated abundant blood flow (Fig. 2a). Positron emission tomography-CT (PET-CT) showed the presence of an increased fluorodeoxyglucose uptake in the mass (Fig. 2b). The maximum standardized uptake value (SUVmax) for the tumor was 4.2. He was diagnosed with a duodenal GIST and then underwent surgery (Fig. 3a). The tumor was an elastic, soft, well-circumscribed, solid mass with a capsule and separated from the duodenum. The tumor was totally excised without resecting any other organs. The finding of the intraoperative frozen section was CD. Macroscopically, the cut surface was flesh-colored and homogenous (Fig. 3b). Histologically, the lymph follicles were markedly increased in number throughout the cortex and medulla with vascular proliferation and hyalinization in the intra- or extrafollicles (Fig. 3c). The germinal centers were atrophic and surrounded by concentrically arranged layers of small lymphocytes (Fig. 3d). The histological finding was the hyaline vascular (HV) variant of $C D$.

The patient was discharged 9 days after surgery without complications and has had no recurrence for 12 months since the resection.

\section{Karger'=}




\section{Case Reports in Gastroenterology}

Case Rep Gastroenterol 2021;15:424-430

DOI: 10.1159/000514394

(C) 2021 The Author(s). Published by S. Karger AG, Basel www.karger.com/crg

Oishi et al.: Castleman's Disease Arising from the Hepatoduodenal Ligament Mimicking a Duodenal Gastrointestinal Stromal Tumor

\section{Discussion}

CD reported by Castleman et al. [1] is an uncertain mass-formative disease of lymph nodes. Those authors described a thymoma-like tumor arising from mediastinum as hyperplasia mediastinal lymph nodes. The most common site of CD is the mediastinum, and abdominal cavity $\mathrm{CD}$ is rare, with $\mathrm{CD}$ arising from the hepatoduodenal ligament being extremely rare. Only few cases have been reported in English [2-4].

Histologically, CD is classified into three variants: HV variant, plasma cell (PC) variant, and mixed variant. Most cases of CD are HV variant (91\%), which is characterized by markedly increased lymph follicles throughout the cortex and medulla with vascular proliferation and hyalinization in the intra- or extra-follicles, along with atrophic germinal centers surrounded by concentrically arranged layers of small lymphocytes in the mantle zone [5]. The PC variant is characterized by the presence of sheets of mature plasma cells in the inter-follicular tissue, the presence of follicle centers, and the absence of vascular proliferation [5].

Clinically, CD is classified into uCD and mCD. The clinical presentations of uCD are asymptomatic. Thus, most cases of $\mathrm{UCD}$ are incidentally detected. In contrast, the clinical presentations of mCD are symptomatic and include a fever, weight loss, anemia, organomegaly, and polyclonal hypergammaglobulinemia [6]. The treatment for uCD is basically surgical resection. If complete excision is performed, the prognosis of patients with uCD is good [7]. In contrast, the treatments for $\mathrm{mCD}$ are systemic therapy with corticosteroids or chemotherapeutic agents, such as monoclonal antibodies to IL-6 or CD20 [6]. The prognosis of patients with mCD is relatively poor due to development of disseminated infection and malignancy.

Radiographically, the imaging findings of $\mathrm{CD}$ are nonspecific, although an abundant blood flow of the lesions sometimes can be detected on color Doppler ultrasonography or dynamic CT. Generally, ultrasonography shows a well-circumscribed, homogenous hypoechoic mass. Color Doppler images on uCD show a pulsating vascular signal extending into the center of the hypoechoic mass. CT for $\mathrm{HV}$ variants of $\mathrm{CD}$ shows a homogenous hypervascular mass smaller than $5 \mathrm{~cm}$ or a heterogenous hypervascular mass larger than $5 \mathrm{~cm}$ with early contrast enhancement [8]. CT for PC variants of CD shows a hypovascular mass. MRI for HV variants of CD shows low intensity on T1-weighted imaging and high intensity on T2-weighted imaging [9]. MRI for PC variants of CD shows no characteristic findings.

In the present case, we preoperatively diagnosed the tumor as a duodenal GIST. GIST is the most common subepithelial tumor of the gastrointestinal tract. Radiologically, when a subepithelial tumor larger than $3 \mathrm{~cm}$ shows hypervascularity on contrast-enhanced CT, GIST should be considered first in the differential diagnosis. On CT, GISTs smaller than $3 \mathrm{~cm}$ typically show well-defined, homogeneous, soft-tissue attenuation masses with variable degrees of enhancement [10].

As the CT features of CD are similar to those of GIST, differentiating between CD and GIST is difficult. The definitive diagnosis of $\mathrm{CD}$ histologically requires a tissue sample, necessitating either surgical resection or a biopsy. EUS-guided fine-needle aspiration (EUS-FNA) for a hypervascular mass carries a risk of inducing bleeding. In the present case, the tumor adjacent to the duodenum was extremely hypervascular, and the image of the tumor arising from the submucosa of the duodenum was not clearly detected by EUS. Thus, considering the risk of bleeding or perforation, EUS-FNA was not performed. CD was instead histologically diagnosed by intraoperative frozen sections.

$\mathrm{CD}$ arising from the hepatoduodenal ligament is rare, and a precise preoperative diagnosis is difficult to make. The preoperative radiological findings in the present case showed early

\section{Karger'=}




\section{Case Reports in Gastroenterology}

\begin{tabular}{l|l}
\hline Case Rep Gastroenterol 2021;15:424-430 \\
\hline DOI: 10.1159/000514394 & $\begin{array}{l}\text { ○ 2021 The Author(s). Published by S. Karger AG, Basel } \\
\text { www.karger.com/crg }\end{array}$ \\
\hline
\end{tabular}

Oishi et al.: Castleman's Disease Arising from the Hepatoduodenal Ligament Mimicking a Duodenal Gastrointestinal Stromal Tumor

enhancement on CT and an arterial flow signal on EUS. However, these findings alone were not sufficient to suggest the possibility of $\mathrm{CD}$. As a result, the patient was histologically diagnosed with the HV variant of $\mathrm{CD}$ and was expected to have a good prognosis, since complete surgical resection had been successfully performed.

We experienced a case of $\mathrm{CD}$ arising from the hepatoduodenal ligament that was difficult to diagnose preoperatively. If a hypervascular solid mass is detected in the abdomen, CD should be considered in the differential diagnosis.

\section{Acknowledgements} editing.

We thank Japan Medical Communication (www.japan-mc.co.jp) for the English language

\section{Statement of Ethics}

This case report was exempted from ethical approval by the Institutional Review Board of National Hospital Organization Higashihiroshima Medical Center. When obtaining informed consent for surgical procedures, the confirmation that the patient had given written informed consent for publication of this case report and the images was obtained.

\section{Conflict of Interest Statement}

The authors declare no conflict of interest.

\section{Funding Sources}

None.

\section{Author Contributions}

K.O. drafted the manuscript. K.O. and T.T. reviewed and edited the manuscript. K.O., K.T., and M.S. participated in the care of the patients. All authors read and approved the final manuscript.

\section{References}

1 Castleman B, Towne VW. Case records of the Massachusetts General Hospital; weekly clinicopathological exercises; founded by Richard C. Cabot. N Engl J Med. 1954 Sep;251(10):396-400.

2 Sato N, Kondo S, Saito K, Hirano S, Hara T, Tanaka E, et al. Hyaline vascular-type Castleman's disease in the hepatoduodenal ligament: report of a case. Surg Today. 2006;36(7):647-50.

3 Karami H, Sahebpour AA, Ghasemi M, Karami H, Dabirian M, Vahidshahi K, et al. Hyaline vascular-type Castleman's disease in the hilum of liver: a case report. Cases J. 2010 Mar;3(1):74.

\section{Karger'=}




\section{Case Reports in Gastroenterology}

\begin{tabular}{l|l}
\hline Case Rep Gastroenterol 2021;15:424-430 \\
\hline DOI: 10.1159/000514394 & $\begin{array}{l}\text { @ 2021 The Author(s). Published by S. Karger AG, Basel } \\
\text { www.karger.com/crg }\end{array}$ \\
\hline
\end{tabular}

Oishi et al.: Castleman's Disease Arising from the Hepatoduodenal Ligament Mimicking a Duodenal Gastrointestinal Stromal Tumor

4 Zhai B, Ren HY, Li WD, Reddy S, Zhang SJ, Sun XY. Castleman disease presenting with jaundice: A case report and review of literature. World J Clin Cases. 2019 Feb;7(3):373-81.

5 Keller AR, Hochholzer L, Castleman B. Hyaline-vascular and plasma-cell types of giant lymph node hyperplasia of the mediastinum and other locations. Cancer. 1972 Mar;29(3):670-83.

6 Casper C. The aetiology and management of Castleman disease at 50 years: translating pathophysiology to patient care. Br J Haematol. 2005 Apr;129(1):3-17.

7 Talat N, Belgaumkar AP, Schulte KM. Surgery in Castleman's disease: a systematic review of 404 published cases. Ann Surg. 2012 Apr;255(4):677-84.

8 Meador TL, McLarney JK. CT features of Castleman disease of the abdomen and pelvis. AJR Am J Roentgenol. 2000 Jul;175(1):115-8.

9 Hill AJ, Tirumani SH, Rosenthal MH, Shinagare AB, Carrasco RD, Munshi NC, et al. Multimodality imaging and clinical features in Castleman disease: single institute experience in 30 patients. Br J Radiol. 2015 May;88(1049):20140670.

10 Lee NK, Kim S, Kim GH, Jeon TY, Kim DH, Jang HJ, et al. Hypervascular subepithelial gastrointestinal masses: CT-pathologic correlation. Radiographics. 2010 Nov;30(7):1915-34.
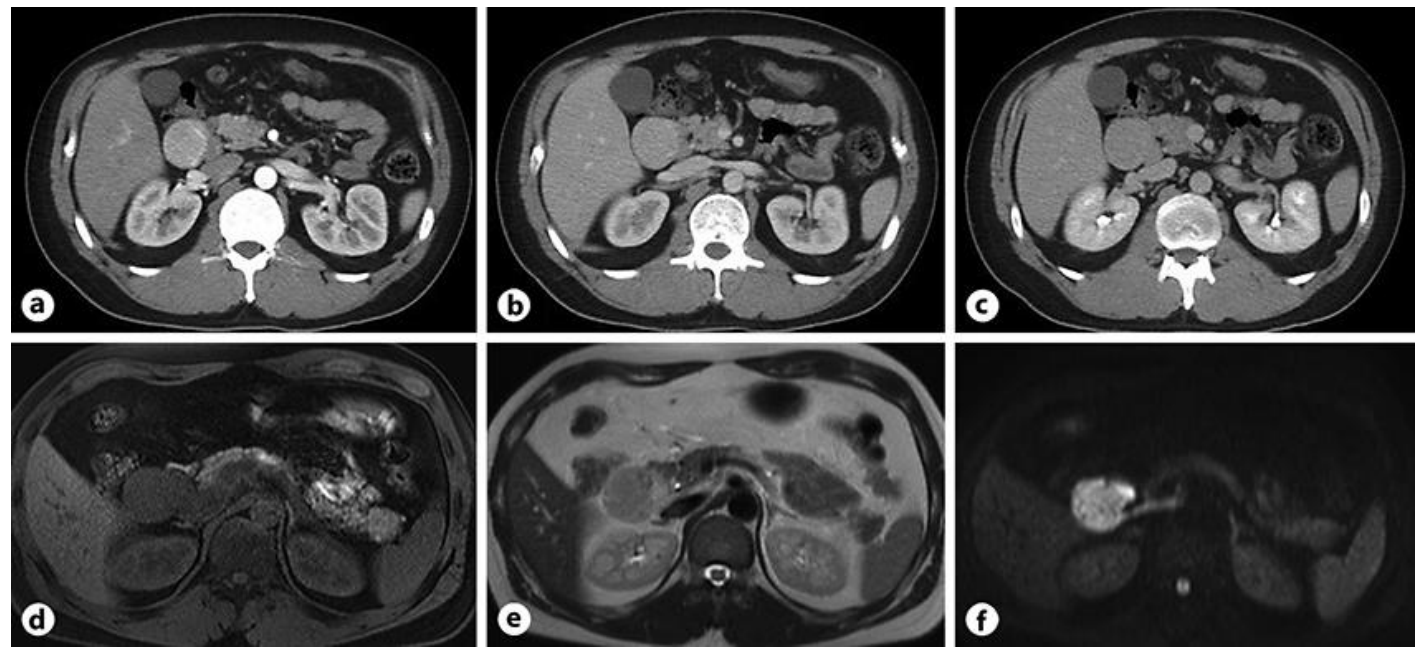

Fig. 1. CT of the abdomen shows an early enhancing mass, $5.2 \mathrm{~cm}$ in diameter, adjacent to the duodenum. a Arterial phase. b Portal phase. $\mathbf{c}$ Late phase. MRI shows a mass in the abdomen with iso-intensity on T1weighted imaging (d), slightly high intensity on T2-weighted imaging (e), and high intensity on diffusionweighted imaging (f).

\section{Karger'=}


Case Reports in Gastroenterology
Case Rep Gastroenterol 2021;15:424-430

DOI: $10.1159 / 000514394$

(c) 2021 The Author(s). Published by S. Karger AG, Basel www.karger.com/crg

Oishi et al.: Castleman's Disease Arising from the Hepatoduodenal Ligament Mimicking a Duodenal Gastrointestinal Stromal Tumor
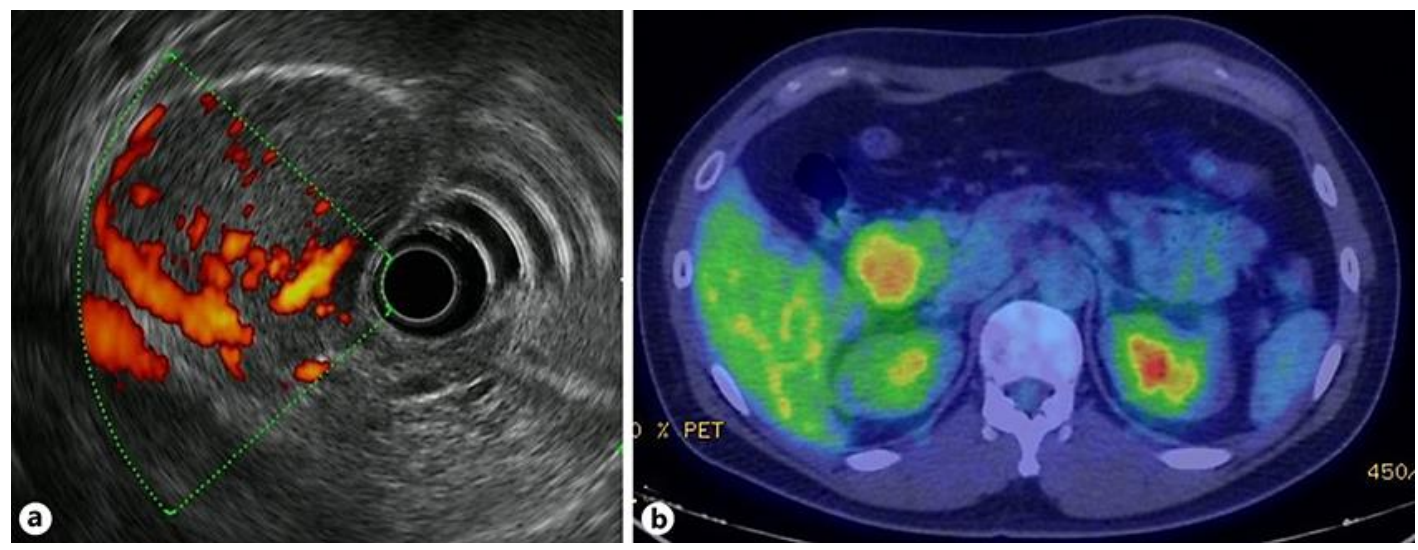

Fig. 2. a Endoscopic ultrasonography shows a well-demarcated hypoechoic mass adjacent to the duodenum. The Doppler echo pattern indicates abundant blood flow. b PET-CT shows increased fluorodeoxyglucose uptake in the mass. 


\section{Case Reports in Gastroenterology}

Case Rep Gastroenterol 2021;15:424-430

DOI: 10.1159/000514394

c) 2021 The Author(s). Published by S. Karger AG, Basel www.karger.com/crg

Oishi et al.: Castleman's Disease Arising from the Hepatoduodenal Ligament Mimicking a Duodenal Gastrointestinal Stromal Tumor
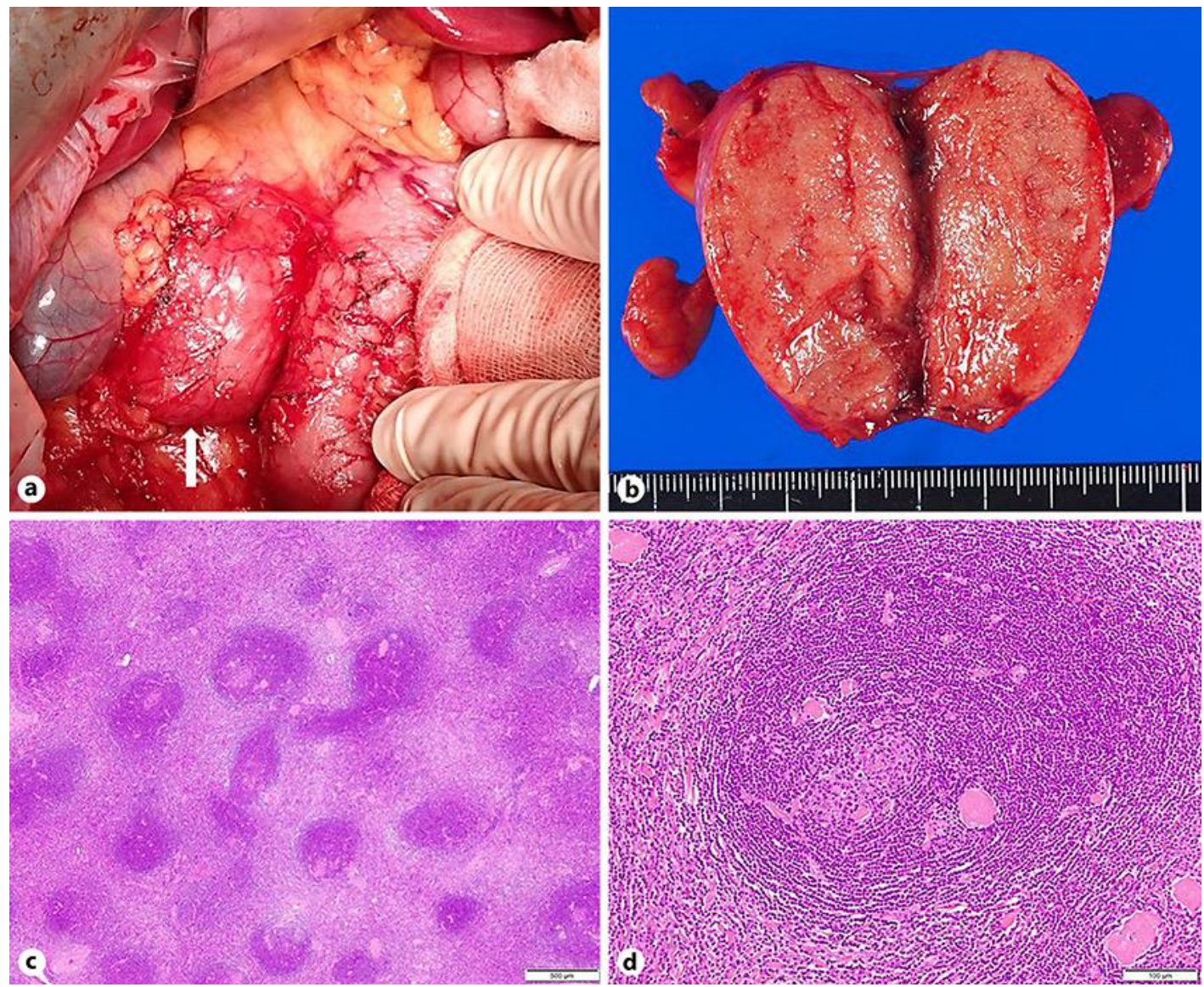

Fig. 3. a Operative image. The arrow indicates the tumor. b A macroscopic image shows a flesh-colored and homogenous tumor. c A histological examination shows that the lymph follicles are markedly increased in number throughout the cortex and medulla with vascular proliferation and hyalinization in the intra- or extra-follicles. $\mathbf{d}$ The germinal centers are atrophic and surrounded by a marginal zone of concentric lymphocytes.

\section{Karger'}

